\title{
Analysis of differences in knowledge of maize farmers who are given training about corn marketing in corn production centers in West Sumatra Province
}

\author{
Ariusni $^{1}$, Sri UlfaSentosa ${ }^{2}$ \\ Universitas Negeri Padang, Indonesia
}

\begin{abstract}
:
This study aims to analyze differences and identify increased knowledge of corn farmers about marketing maize in corn production centers. The research methods used include: 1). Determination of population and sample. The population in this study were corn farmers and experts. The sample of corn farmers was 90 people. Sampling was done by purposive sampling. 2) Collection Method. Primary data were collected using a questionnaire. In addition, the primary data collected through the application of a quasi-experimental design that will be used is the Non-Equivalent Control Group Design. 4) Data analysis methods: a) To analyze the data using the difference between the two parameters on average, using 2 nonhomogeneous samples analysis. Data collection was carried out in the field by distributing questionnaires to corn farmers who had been given training and also to corn farmers who had not been given training. The results of the study found that (a) there were differences in the knowledge and understanding of corn farmers who were given training with the control group who were not given training on (1). marketing of corn products through agricultural cooperatives; (2). corn marketing model; (3). engineering model for corn marketing of maize farmers in corn production centers in West Sumatra Province. (b). However, there is no difference in knowledge between the two farmer groups regarding the marketing margins of maize commodities in the maize production center areas in West Sumatra Province.
\end{abstract}

Keywords: Different test, Experimental design, marketing knowledge. 